\title{
The Use of Corticosteroid in The Treatment of Central Giant Cell Granuloma
}

\author{
Huseyin GULCAN 國, Ugur GULSEN [i] ${ }^{1}$, Elif Aslı GULSEN 國 ${ }^{2}$
}

\begin{abstract}
Central giant cell granuloma (CGCG), an infrequent disease, is a non-neoplastic bone lesion. Clinically, it may be asymptomatic or it may show an aggressive and painful condition that can cause root resorption, cortical bone destruction. The aim of this report is to emphasize the importance of intralesional corticosteroid injection, which is a less invasive technique in the treatment of CGCG. 24 years old female patient came to our clinic with pain and swelling in the left side of the mandible. In intraoral examination, a red-purple swelling, which was found to have been present for 6 months, was detected in this region. Radiographic examination showed a multilocular radiolucent lesion and root resorption. Biopsy was done under local anesthesia. After the histopathological examination, the diagnosis of CGCG was done. Intralesional corticosteroid injection was applied. During routine follow-up, the lesion was observed to decrease and disappear.
\end{abstract}

Keywords: Giant cell; granuloma; steroid.

\section{Santral Dev Hücreli Granülom Tedavisinde Kortikosteroid Kullanımı}

\section{Öz}

S1k görülmeyen bir hastalık olan santral dev hücreli granülom (SDHG), neoplazik olmayan bir kemik lezyonudur. Klinik olarak asemptomatik olabilir ya da kök rezorpsiyonu, kortikal kemik yıkımı gibi agresif ve ağrılı bir durum gösterebilir. $\mathrm{Bu}$ olgu sunumunun amacı santral dev hücreli granülom tedavisinde daha az invaziv bir yöntem olan lezyon içi kortikosteroid enjeksiyonunun önemini vurgulamaktır. 24 yaşında kadın hasta mandibula sol bölgede ağrı ve şişlikle kliniğe başvurdu. Ağız içi muayenede, bu bölgede 6 aydır bulunduğu öğrenilen kırmızı-mor renkli şişlik tespit edildi. Radyografik muayenede multiloküler radyolüsent lezyon ve diş köklerinde rezorpsiyon tespit edildi. Lokal anestezi altında biyopsi yapıldı. Yapılan histopatolojik incelemenin ardından SDHG tanısı kondu. Hastaya lezyon içi kortikosteroid enjeksiyonu uygulandı. Rutin takiplerde lezyonun küçülüp kaybolduğu görüldü.

Anahtar Kelimeler: Dev hücre; granülom; steroid.

\section{INTRODUCTION}

Central giant cell granuloma (CGCG) is a benign lesion and its etiology is unknown (1). It typically occurs in the 2nd and 3rd decades (average age 25). It is more common in women. Lesions are mostly seen in the lower jaw, especially in the body and anterior region of the mandible. Lesions are radiolucent and mostly multilocular (2). It can also be small and unilocular in early stages. In larger lesions, septa formation, egg-shell appearance and perforation of cortical bone can be seen (3). It can cause resorption and mobilization of teeth. Most patients are asymptomatic, but complaints such as pain and paresthesia may occur, especially in aggressive lesions (2).

The radiological characteristics of the lesion is not specific. Radiological features of some lesions (e.g. hyperparathyroidism, fibrous dysplasia, aneurysmal bone cysts and fibro-osseous lesions) are similar to CGCG (3).

1 Zonguldak Bulent Ecevit University Faculty of Dentistry, Oral and Maxillofacial Surgery Department, Zonguldak, Turkey

2 Zonguldak Oral and Dental Health Center, Zonguldak, Turkey

* This case was presented as a poster presentation at the congress of the Turkish Oral and Maxillofacial Surgery Association held in Bodrum in 2017.

Sorumlu Yazar / Corresponding Author: Hüseyin GÜLCAN, e-mail: huseyingulcan@windowslive.com

Geliş Tarihi / Received: 12.11.2020, Kabul Tarihi / Accepted: 19.02.2021 
CGCG can also affect bones outside of the jaws. These are mostly the craniofacial region and small long bones such as hand and foot (4). Microscopically, CGCG is similar to aneurysmal bone cyst, hyperparathyroidism and cherubism. CGCG is basically the same with the osteolytic lesions in hyperparathyroidism, but serum calcium and parathormone levels are elevated in hyperparathyroidism (2). Malign transformation of this lesion is very rare (5). Chung et al. divided this disease into two groups as aggressive and non-aggressive according to their clinical and radiological features. Nonaggressive lesions do not make perforation to the cortical bone and show slow occurrence. This group is almost completely asymptomatic and has low recurrence rate. Aggressive lesions cause pain, resorption of root and cortical bone perforation. They grow rapidly and have high rate of recurrence after curettage (6).

The most common treatment of this disease is surgical removal. Surgical procedures range from simple curettage to en bloc resection. Curettage is combined with cryosurgery in some cases $(7,8)$. The aim of this study is to show that intralesional corticosteroid injection applied in the treatment of CGCG is a less invasive method and it preserves the integrity of the surrounding vital tissues better.

\section{CASE REPORT}

A 24 years old female patient was referred to clinic with facial asymmetry, pain and swelling in the left lower jaw. In the intraoral examination, a red-purple and palpable swelling, which was extending from the left second incisor to the first molar area in the mandible, was detected. It was learned from the anamnesis taken from the patient that this swelling had been present for 6 months. Written informed consent was obtained. Cone beam computed tomography and panoramic radiography examination showed a multilocular radiolucent lesion and resorption in some teeth (Figure 1A, 1B, 2A, 2B).

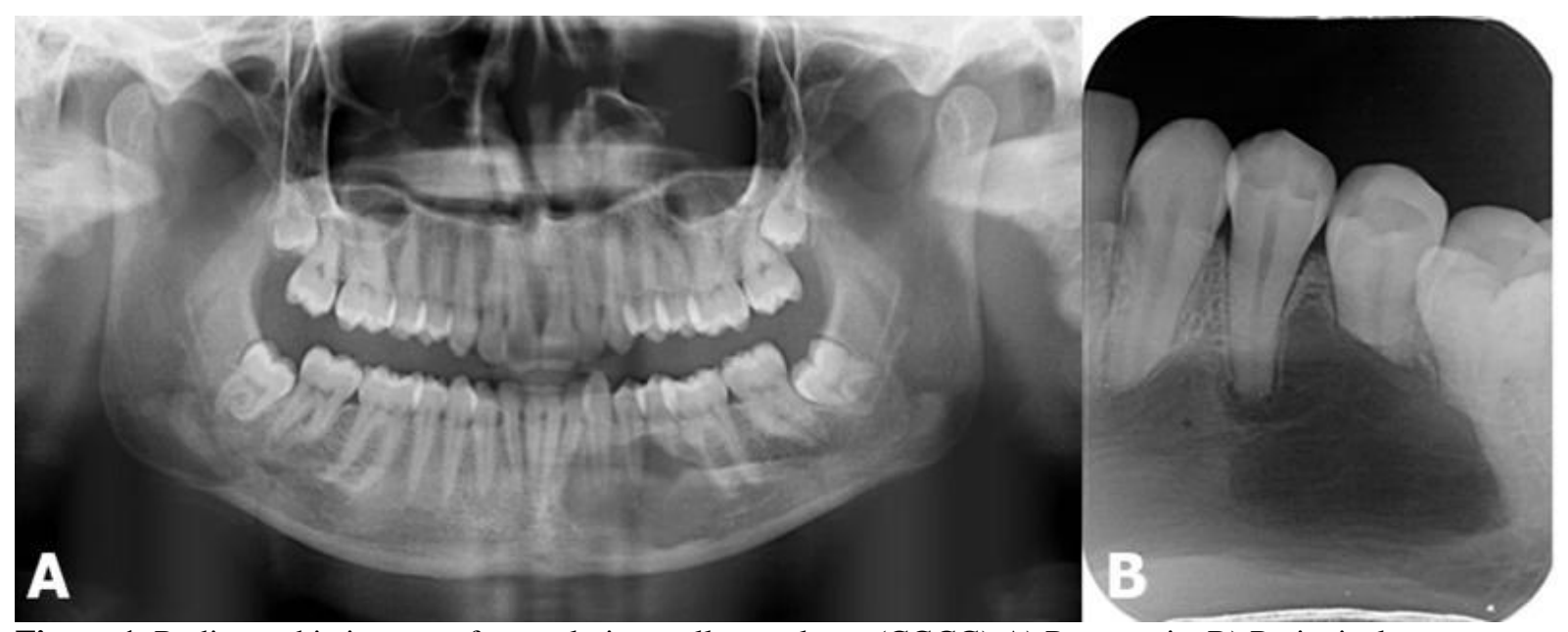

Figure 1. Radiographic images of central giant cell granuloma (CGCG) A) Panoramic, B) Periapical

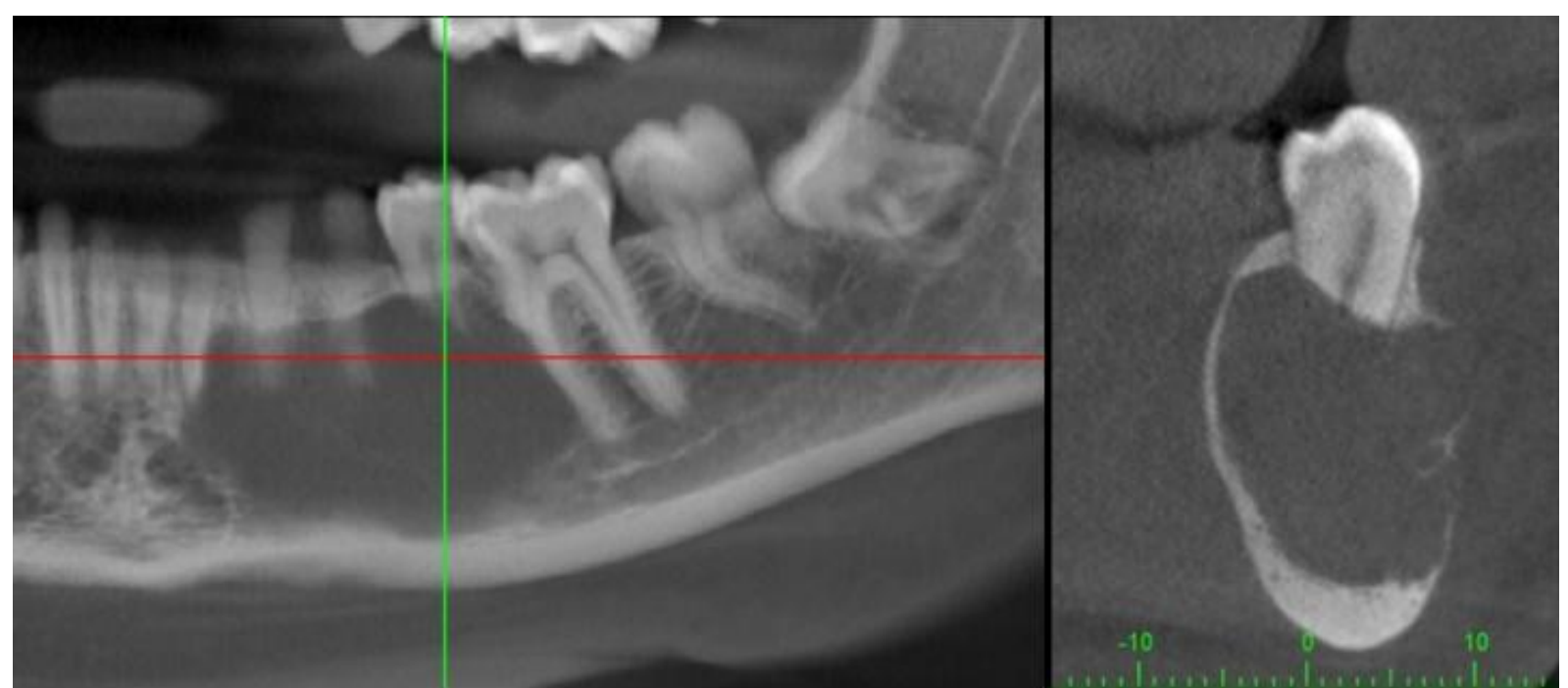

Figure 2. A) Cone beam computerized tomography scan of the lesion. B) Coronal view of the CBCT scan showing the lesion, and resorption of the second premolar tooth

The patient was referred to the department of internal diseases for hormone tests and it was found that she didn't have hyperparathyroidism. Biopsy was done under local anesthesia. In the histopathological examination, reaction with CD68 and proliferation with Ki-67 were observed. No reaction was observed with pancytokeratin, S-100, factor 13a, SMA, desmin and vimentin. As a result of the examination, diagnosis of CGCG was made. 
Intralesional corticosteroid was applied to the patient under local anesthesia every ten days for two months. Intralesional corticosteroid injection was made in accordance with the protocol described by Terry and Jacoway (9). According to this protocol, triamcinolone acetonide and a local anesthetic (bupivacaine $0.5 \%$ ) are mixed equally and applied. The recommended dose is 2 $\mathrm{ml}$ for a $2 \mathrm{~cm}$ lesion. In our case, 2 ampoules of $40 \mathrm{mg} / \mathrm{ml}$ triamcinolone acetonide were mixed with bupivacaine in equal proportions, and the bone was perforated with 21- gauge needle and the mixture was injected into the lesion. After the procedure, a significant reduction in the lesion was observed in the patient, who was followed up with routine radiographs (Figure 3A, 3B). The mucosa of the lesion area in the mouth reached its normal color over time with the injection. When the radiograph taken at the end of 18 months was compared with the first one, it was observed that the bone radiopacity increased and the lesion disappeared completely (Figure 4).

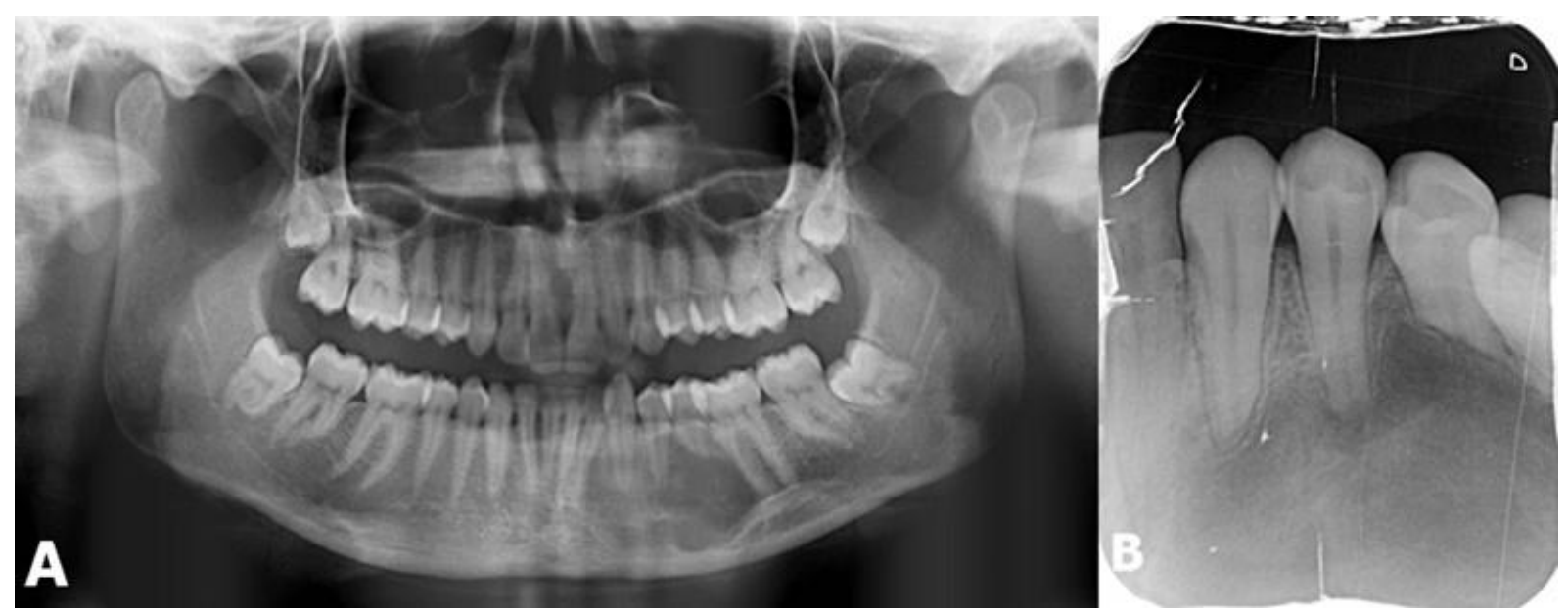

Figure 3. A) Panoramic radiograph 6 months after injection B) Periapical radiograph 7 months after injection

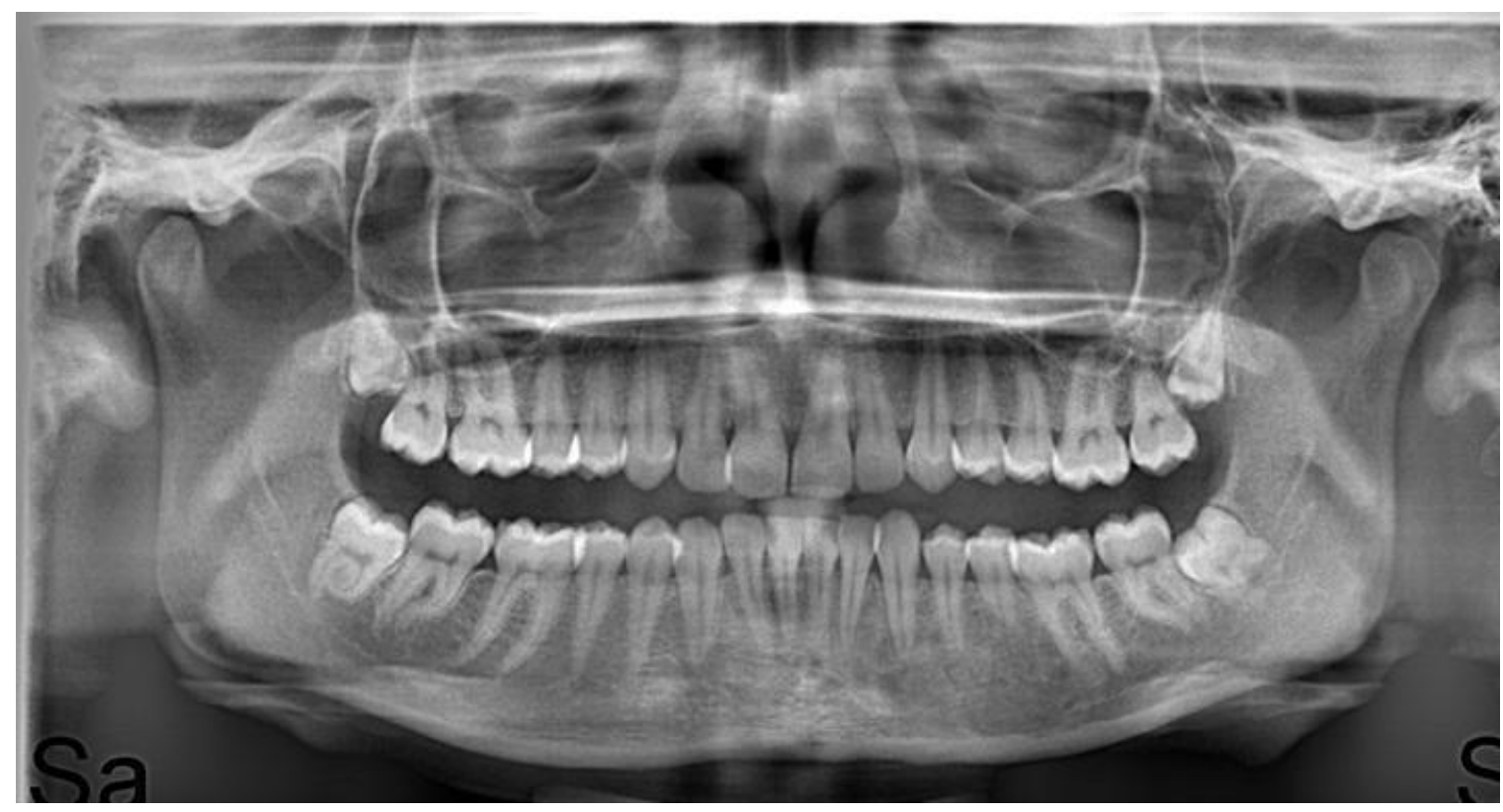

Figure 4. Panoramic radiograph after 18 months

\section{DISCUSSION}

There are different treatment methods in CGCG treatment. The recommended treatment for aggressive or recurrent lesions is en bloc resection. However, this treatment creates large defects that lead to undesirable facial contour changes, especially in children and young adults (10). Therefore, less invasive treatment options were considered in our study.

Another treatment option is calcitonin therapy. However, the duration of calcitonin therapy, which is one of the non-surgical methods, is very long (about 1 year) and daily subcutaneous injection becomes a difficult situation for patients. In addition, long-term studies suggest that

the use of nasal calcitonin sprays increases the risk of liver cancer $(11,12)$. Other methods include simple curettage, radiotherapy, interferon, biphosphonate, denosumab and intralesional corticosteroid injection (11). Intralesional corticosteroid injection is another nonsurgical method in the treatment of CGCG and its effectiveness has been demonstrated in many studies (1315). There are various hypotheses regarding the effect of steroids on CGCG. In an in vitro study by Kremer et al. (16), when human osteoclast like giant cell tumor and 
avian osteoclast cells are treated with $17 \beta$-estradiol, bone resorption is reduced. Kameda et al. (17) showed that $17 \beta$-estradiol reduced osteoclastic bone resorption and Hiramaya et al. (18) reported that dexamethasone reduced bone resorption caused by mature osteoclasts. Considering all these reasons, intralesional steroid injection was chosen as the treatment modality in our study.

In the treatment of CGCG, intralesional corticosteroid injection is a type of treatment that eliminates the need for surgery and prevents the formation of functional and aesthetic defects by protecting the teeth and surrounding vital tissues.

Authors's Contributions: Idea/Concept: H.G., U.G., E.A.G.; Design: H.G., U.G., E.A.G.; Data Collection and/or Processing: H.G., U.G., E.A.G.; Analysis and/or Interpretation: H.G., U.G.; Literature Review: H.G., U.G.; Writing the Article: H.G., U.G., E.A.G.; Critical Review: H.G., U.G., E.A.G.

\section{REFERENCES}

1. de Lange J, van den Akker HP, van den Berg H. Central giant cell granuloma of the jaw: a review of the literature with emphasis on therapy options. Oral Surg Oral Med Oral Pathol Oral Radiol Endod. 2007; 104(5): 603-15.

2. Regezi JA. Odontogenic cysts, odontogenic tumors, fibroosseous, and giant cell lesions of the jaws. Mod Pathol. 2002; 15(3): 331-41.

3. Bodner L, Bar-Ziv J. Radiographic features of central giant cell granuloma of the jaws in children. Pediatr Radiol. 1996; 26(2): 148-51.

4. Yamaguchi T, Dorfman HD. Giant cell reparative granuloma: a comparative clinicopathologic study of lesions in gnathic and extragnathic sites. Int J Surg Pathol. 2001; 9(3): 189-200.

5. Mintz GA, Abrams AM, Carlsen GD, Melrose RJ, Fister HW. Primary malignant giant cell tumor of the mandible. Report of a case and review of the literature. Oral Surg Oral Med Oral Pathol. 1981; 51(2): 164-71.

6. Chuong R, Kaban LB, Kozakewich H, Perez-Atayde A. Central giant cell lesions of the jaws: a clinicopathologic study. J Oral Maxillofac Surg. 1986; 44(9): 708-13.

7. Kara I, Ozan F, Polat S. Agresif tip maksillar santral dev hücreli granulomada konservatif tedavi yaklaşımı: 2 olgu sunumu. Cumhuriyet Dental Journal. 2011; 11(2): 108-12.

8. Webb DJ, Brockbank J. Combined curettage and cryosurgical treatment for the aggressive "giant cell lesion" of the mandible. Int J Oral Maxillofac Surg. 1986; 15(6): 780-5.

9. Terry B, Jacoway J. Management of central giant cell lesions: an alternative to surgical therapy. Oral Maxillofac Surg Clin North Am. 1994; 6(3): 579-600.

10. Shirani G, Abbasi AJ, Mohebbi SZ, Shirinbak I. Management of a locally invasive central giant cell granuloma (CGCG) of mandible: report of an extraordinary large case. J Craniomaxillofac Surg. 2011; 39(7): 530-3.
11. Dolanmaz D, Esen A, Mihmanlı A, Işık K. Management of central giant cell granuloma of the jaws with intralesional steroid injection and review of the literature. Oral Maxillofac Surg. 2016; 20(2): 2039 .

12. Sun LM, Lin MC, Muo $\mathrm{CH}$, Liang JA, Kao $\mathrm{CH}$. Calcitonin nasal spray and increased cancer risk: a population-based nested case-control study. J Clin Endocrinol Metab. 2014; 99(11): 4259-64.

13. Choi JW, Kraut RA. Management of central giant granuloma of mandible with intralesional triamcinolone injections: a case report. N Y State Dent J. 2013; 79(3): 34-6.

14. Kermer C, Millesi W, Watzke IM. Local injection of corticosteroids for central giant cell granuloma. A case report. Int J Oral Maxillofac Surg. 1994; 23(6 Pt 1): 366-8.

15. Rajeevan NS, Soumithran CS. Intralesional corticosteroid injection for central giant cell granuloma. A case report. Int J Oral Maxillofac Surg. 1998; 27(4): 303-4.

16. Kremer M, Judd J, Rifkin B, Auszmann J, Oursler MJ. Estrogen modulation of osteoclast lysosomal enzyme secretion. J Cell Biochem. 1995; 57(2): 2719.

17. Kameda T, Mano H, Yuasa T, Mori Y, Miyazawa K, Shiokawa M, et al. Estrogen inhibits bone resorption by directly inducing apoptosis of the bone-resorbing osteoclasts. J Exp Med. 1997; 186(4): 489-95.

18. Hirayama T, Sabokbar A, Athanasou NA. Effect of corticosteroids on human osteoclast formation and activity. J Endocrinol. 2002; 175(1): 155-63. 